\title{
Indole Derivative Interacts with Estrogen Receptor Beta and Inhibits Human Ovarian Cancer Cell Growth
}

\author{
Laura Verardi $^{1}$, Jessica Fiori ${ }^{2}$, Vincenza Andrisano ${ }^{3}$, Alessandra Locatelli ${ }^{1}$, Rita Morigi ${ }^{1}$ (D), \\ Marina Naldi $\left.{ }^{1,4}{ }^{(}\right)$, Carlo Bertucci ${ }^{1}$, Elena Strocchi ${ }^{5}$, Carla Boga ${ }^{5, *} \mathbb{0}$, Gabriele Micheletti ${ }^{5}(\mathbb{C}$ \\ and Natalia Calonghi ${ }^{1, *}$ \\ 1 Department of Pharmacy and Biotechnology, University of Bologna, 40121 Bologna, Italy; \\ laura.verardi88@gmail.com (L.V.); alessandra.locatelli@unibo.it (A.L.); rita.morigi@unibo.it (R.M.); \\ marina.naldi@unibo.it (M.N.); carlo.bertucci@unibo.it (C.B.) \\ 2 Department of Chemistry 'G. Ciamician', University of Bologna, Via Selmi, 2, 40126 Bologna, Italy; \\ jessica.fiori@unibo.it \\ 3 Department for Life Quality Studies, University of Bologna, Corso D'Augusto 237, 47921 Rimini, Italy; \\ vincenza.andrisano@unibo.it \\ 4 Centre for Applied Biomedical Research-CRBA, University of Bologna, St. Orsola Hospital, 40126 Bologna, Italy \\ 5 Department of Industrial Chemistry 'Toso Montanari', University of Bologna, Viale Del Risorgimento, 4, \\ 40136 Bologna, Italy; elena.strocchi@unibo.it (E.S.); gabriele.micheletti3@unibo.it (G.M.) \\ * Correspondence: carla.boga@unibo.it (C.B.); natalia.calonghi@unibo.it (N.C.); \\ Tel.: +39-051-2093616 (C.B.); +39-051-2091231 (N.C.)
}

Academic Editors: Pascale Moreau, Simona Collina and Diego Muñoz-Torrero Received: 9 June 2020; Accepted: 25 September 2020; Published: 27 September 2020

\begin{abstract}
Ovarian cancer remains the leading cause of mortality among gynecological tumors. Estrogen receptor beta (ER $\beta$ ) expression has been suggested to act as a tumor suppressor in epithelial ovarian cancer by reducing both tumor growth and metastasis. ER $\beta$ expression abnormalities represent a critical step in the development and progression of ovarian cancer: for these reasons, its re-expression by genetic engineering, as well as the use of targeted ER $\beta$ therapies, still constitute an important therapeutic approach. 3-\{[2-chloro-1-(4-chlorobenzyl)-5-methoxy-6methyl-1H-indol-3-yl]methylene\}-5-hydroxy-6-methyl-1,3-dihydro- $2 \mathrm{H}$-indol-2-one, referred to here as compound 3, has been shown to have cytostatic as well cytotoxic effects on various hormone-dependent cancer cell lines. However, the mechanism of its anti-carcinogenic activity is not well understood. Here, we offer a possible explanation of such an effect in the human ovarian cancer cell line IGROV1. Chromatin binding protein assay and liquid chromatography mass spectrometry were exploited to localize and quantify compound 3 in cells. Molecular docking was used to prove compound 3 binding to ER $\beta$. Mass spectrometry-based approaches were used to analyze histone post-translational modifications. Finally, gene expression analyses revealed a set of genes regulated by the ER $\beta / 3$ complex, namely CCND1, MYC, CDKN2A, and ESR2, providing possible molecular mechanisms that underline the observed antiproliferative effects.
\end{abstract}

Keywords: indole derivative; ovarian cancer; estrogen receptor beta; histones; LC/ESI/MS; molecular docking

\section{Introduction}

Ovarian cancer is the second most common cancer in women over the age of 40, particularly in developed countries [1]. If compared to all types of cancers, it is the eleventh most common type in women, the fifth leading cause of cancer related death in women, and the most fatal gynecologic cancer [2]. 
Estrogens, as the main female sex steroids, have important functions in the regulation of cellular processes such as growth and differentiation in human ovary and endometrium. Their effects are mediated by two receptors, namely estrogen receptor alpha $(E R \alpha)$ and estrogen receptor beta $(E R \beta)$, which belong to the nuclear receptor superfamily and act as ligand-activated transcription factors [3]. $\mathrm{ER} \beta$ is known to act as an ER $\alpha$ antagonist in specific settings, and their balance is important for their action [4-6]. Overall, ER $\alpha$ is thought to promote the expression of genes involved in cell survival and proliferation, thus determining tumor growth and progression, while the natural function of ER $\beta$ is thought to be antiproliferative and proapoptotic, and ER $\beta$ is therefore described as a tumor suppressor. Indeed, it is known that the antiproliferative effect of ER $\beta$ is accompanied by downregulation in the expression of CYCLINE D1 (CCND1), a cell cycle regulator overexpressed in epithelial, ovarian, and breast cancers [7-10]. Several ER $\beta$ isoforms have been reported thus far; in the normal ovary, the levels of $\mathrm{ER} \beta$ are high and predominant over $\mathrm{ER} \alpha$, being $\mathrm{ER} \beta 1, \beta 2$, and $\beta 5$ the most represented ones [11]. Therefore, $E R \beta$ is the only fully functional isoform that is able to form homodimers or heterodimers with $E R \alpha$, whereas $E R \beta 2$ and $\beta 5$ do not form homodimers and have no innate activities of their own, but may modulate estrogen action when dimerized with ER $\beta$ or ER $\alpha$ [12]. Unfortunately, studies on the functional roles of ER $\beta 2$ and $\beta 5$ in ovarian cancers are limited. In some papers, the authors have demonstrated ER $\beta 5$-induced cell migration, invasion, and proliferation, while ER $\beta 2$ was shown to affect ovarian cell migration and invasion, but not proliferation $[13,14]$. Moreover, ER $\beta 2$ has been reported to correlate with chemoresistance [15].

Other authors have reported that in ovarian epithelial tumors there is a loss of ER $\beta$ expression and a relationship of the $\operatorname{ER} \beta / \mathrm{ER} \alpha$ ratio, compared to normal ovarian tissue [6-16]. Furthermore, a complete loss of ER $\beta$ was observed in the metastases of ovarian tumors, while low expression levels were still measurable in the presence of primary tumors [17]. A positive correlation of ER $\beta$ expression with survival has been demonstrated in patients with ovarian cancer and animal models [18,19]. If ER $\beta$ expression abnormalities represent a critical step in the development and progression of several cancers including ovarian cancer, its re-expression by genetic engineering, as well as the use of targeted ER $\beta$ therapies, may constitute important new therapeutic approaches.

Among them, an important role is played by the development of efficient ER $\beta$ agonists. Recently, estrogenic activities of non-steroidal selective ER $\beta$ agonists such as SERBA-1, 20], WAY-202196 [20], and Liquiritigenin [21] have been reported (Figure 1). Other ER $\beta$ agonists are ERB-041 [20], WAY200070 [22], WAY-29 [23], and WAY-659 [23] (Figure 1).

Despite the well-known activity conferred by the presence of the indole scaffold in drugs and pharmaceuticals, including anticancer agents, benzoxazole is the main heterocyclic moiety of many $\mathrm{ER} \beta$ agonists. However, some indole moieties are in the structure of Bizelesin, a drug used in clinical trials of treatment of solid tumors, including ovary cancer [24]. In the past, we reported the synthesis and a first screening of the biological activity of a small library of Knoevenagel adducts, which were synthesized by reacting oxindoles (2) with indole aldehydes (1) properly substituted [25]. Among them, 3-\{[2-chloro-1-(4-chlorobenzyl)-5-methoxy-6-methyl-1H-indol-3-yl]methylene\}-5-hydroxy-6methyl-1,3-dihydro-2H-indol-2-one (3) (Scheme 1) emerged as a lead compound owing to its significant growth inhibition of cancer cells. Actually, in a primary screening, compound 3 was subjected to the Developmental Therapeutics Program (DTP) at the National Cancer Institute (Bethesda, MD) where it came out to exert a cytostatic but not cytotoxic activity, restricted to leukemia, brain, ovarian, kidney, prostate, and breast cancer cell lines [25]. Compared to other compounds found to be active on ovarian cancer cell lines, compound 3 caused the accumulation of IGROV1 cells in the G0/G1 phase, not in the G2/M phase. Moreover, compound 3 showed no significant effect on tubulin polymerization, indicating that this compound does not interfere with microtubule dynamics, further differentiating it from other leads (i.e., $\mathbf{3 g}$ and $\mathbf{3 f}$ [25]) that arrest cells in mitosis, confirmed by the condensation of tubulin (marker of cytoskeleton reorganization). These promising results on compound 3 and the growing interest in the development of valid ER $\beta$ agonists motivated us to investigate more deeply its molecular mechanism of action as a possible ER $\beta$ agonist. Interestingly, from an experimental point of 
view, this compound is fluorescent and can be monitored by fluorescence-based methods (excitation at $488 \mathrm{~nm}$ and emission at $530 \mathrm{~nm}$ ).

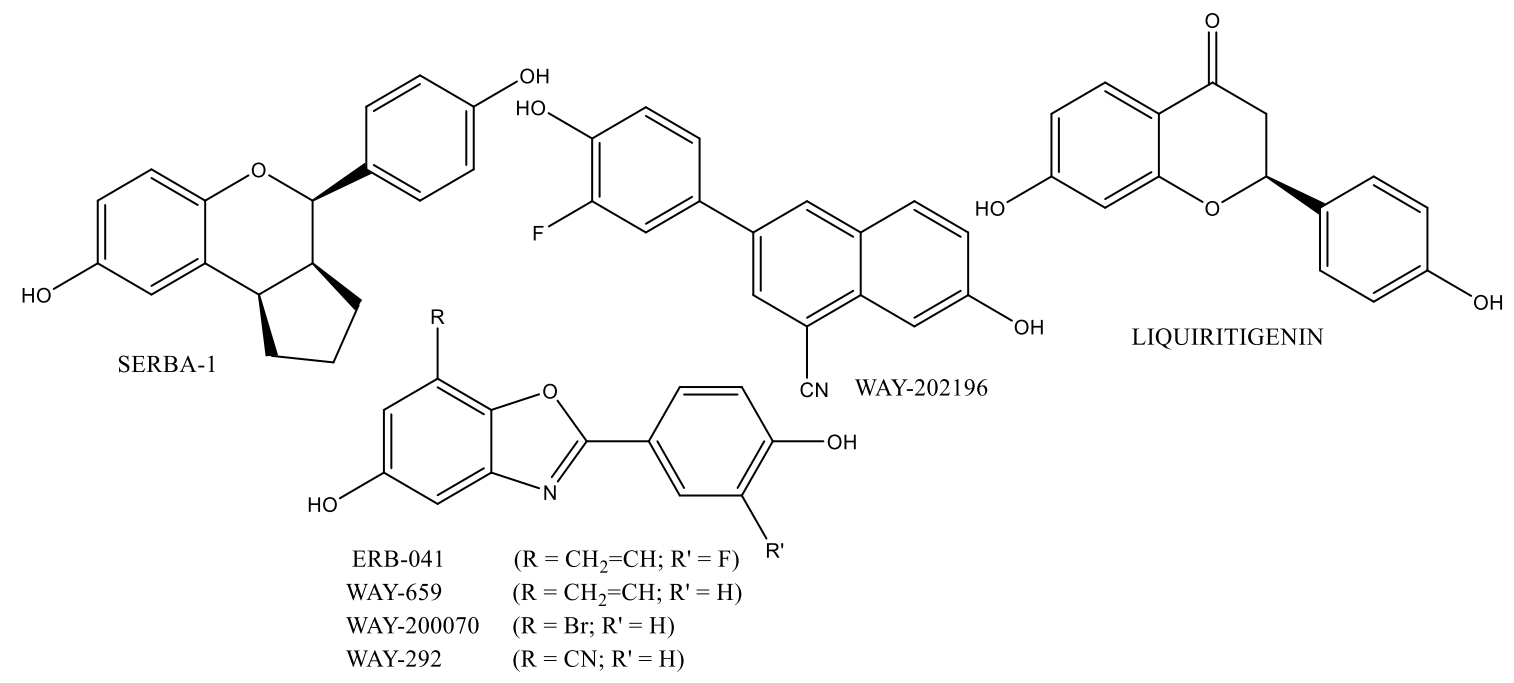<smiles>Cc1c[nH]c2c(O)cc3c(c12)[C@H](CCl)CN3C(=O)c1cc2cc(NC(=O)Nc3ccc4[nH]c(C(=O)N5C[C@@H](CCl)c6c5cc(O)c5[nH]cc(C)c65)cc4c3)ccc2[nH]1</smiles>

Figure 1. Non-steroidal selective ER $\beta$ agonists belonging to different classes of organic compounds.<smiles>COc1cc2c(C=O)c(Cl)n(Cc3ccc(Cl)cc3)c2cc1C</smiles><smiles>Cc1cc2c(cc1O)CC(=O)N2</smiles><smiles>COc1cc2c(/C=C3/C(=O)Nc4cc(C)c(O)cc43)c(Cl)n(Cc3ccc(Cl)cc3)c2cc1C</smiles>

Scheme 1. Synthesis of compound 3 [25].

In this paper, we report the results of the studies on the impact of this molecule on the proliferation of ovarian cancer cell line IGROV1, by confirming the effect of compound 3 on cell growth; investigating the expression of key cell cycle regulators, ER $\beta$ colocalization, and changes in the histones post-translational modifications pattern; and performing molecular docking. 


\section{Results}

\subsection{Biological Activity}

2.1.1. Compound 3 Inhibits IGROV1 Ovarian Cancer Cells Proliferation and Progression in the Cell Cycle

IGROV1 cells were treated with compound $3(5 \mu \mathrm{M}$, corresponding to the concentration that induces $50 \%$ of growth inhibition) for $72 \mathrm{~h}$ and the cell number determined by the Trypan Blue dye exclusion method. As depicted in Figure 2a, compound 3 drastically inhibits the proliferation of ovarian cancer cells. IGROV1 cells were treated with compound 3 for 24,48 , and $72 \mathrm{~h}$ and analyzed by flow cytometry after DNA staining. Untreated cells progress through the cell cycle; in contrast, compound 3 treated IGROV1 cells accumulate in the G0/G1 phase in a time-dependent manner, with a nearly complete synchronization (87\%) after $72 \mathrm{~h}$ of treatment. The flow cytometric analyses along with the relative phase percentages are shown in Figure $2 \mathrm{~b}$. The set of experiments was designed to address whether cells withdrawn from the cell cycle by compound 3 could reenter it and proliferate in response to the administration of an exogenous hormone, $17 \beta$-estradiol (E2). As shown in Figure 2c, E2 treatment leads to an increase in proliferation in serum-starved cells (ss), but it does not exert any effect in compound 3 treated cells.
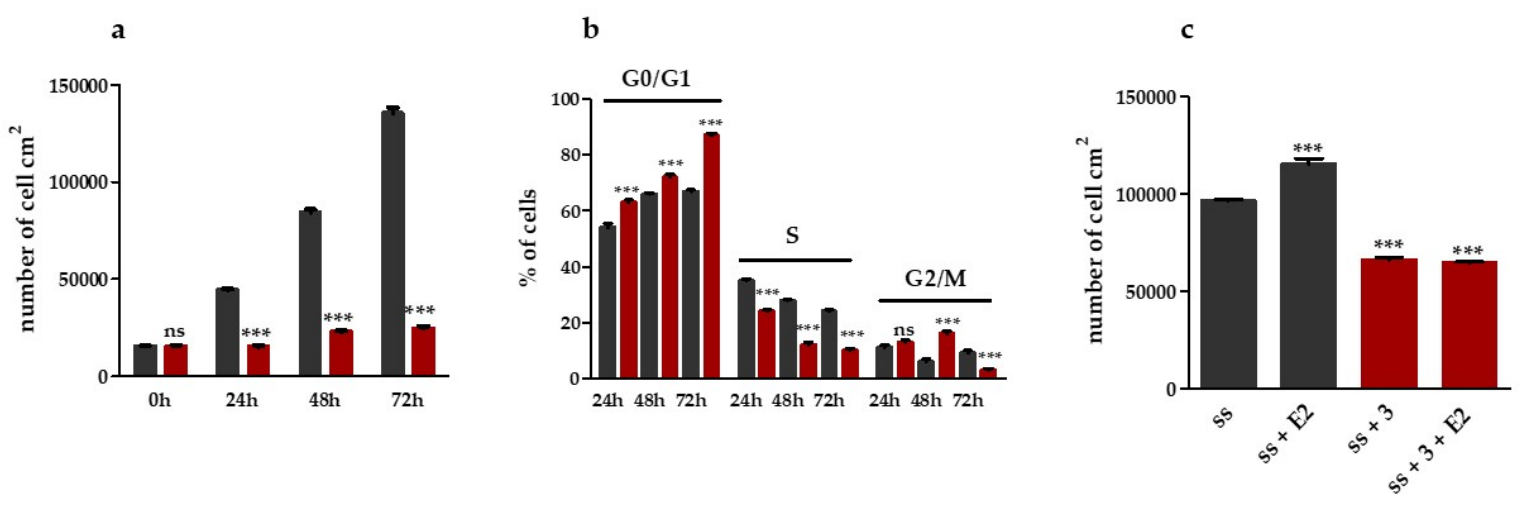

Figure 2. Compound 3 inhibits IGROV1 cells growth: (a) IGROV1 cells viability after treatment with 3 (red) is compared with untreated cells (gray); (b) IGROV1 cells were treated with compound 3 (red) and the isolated nuclei stained with PI were analyzed by flow cytometry; and (c) E2 induces proliferation in serum starved (ss) but not in compound 3 treated IGROV1. Cells were serum starved or treated with $5 \mu \mathrm{M}$ compound 3 for $24 \mathrm{~h}$. Each group was then stimulated with $1 \mathrm{nM}$ E2 and cell growth measured. Statistical analysis was carried out using Prism GraphPad ${ }^{* * *} p<0.001$. n.s., not significant.

$\mathrm{ER} \alpha$ or ER $\beta$ interaction with compound 3 was investigated by confocal microscopy. Both ERs were visualized by fluorescent specific antibodies (red fluorescence) and compound 3 using its inherent fluorescence (green). Figure 3 shows how ER $\alpha$ and compound 3 are diffused in cellular compartments of IGROV1, but the merging indicates that they do not colocalize. On the contrary, ER $\beta$ and compound 3 colocalize mostly in the nuclear compartment. Unfortunately, a triple staining to highlight the nucleus with dyes such as DAPI and or Hoechst is not possible because the excitation spectrum of compound 3 partially overlaps with those of the nuclear dyes. For this reason, different techniques were exploited to assess the nuclear localization of the compound 3 and its interaction with the ER $\beta$, thus confirming the interpretation of the results obtained by confocal microscopy. 


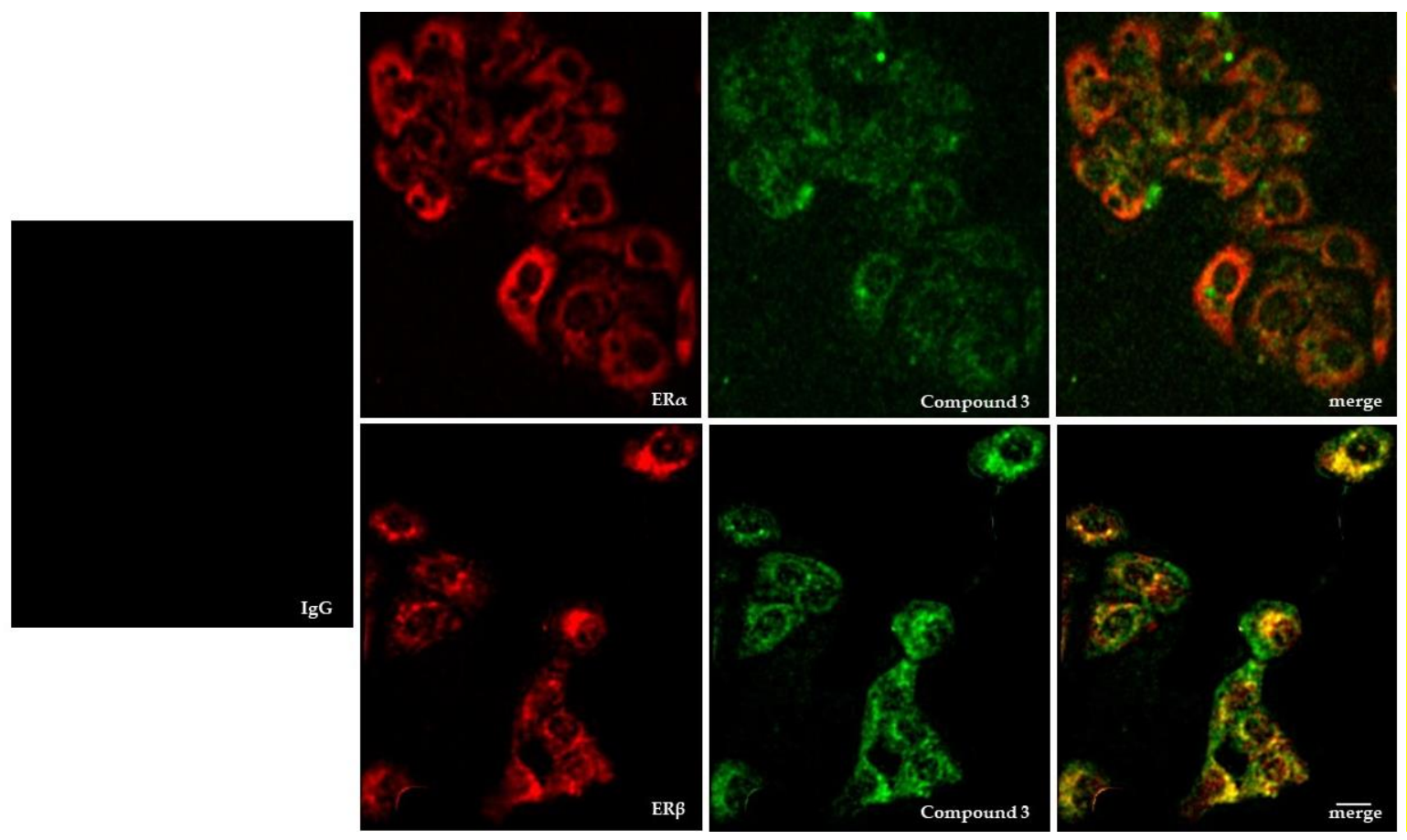

Figure 3. ER $\beta / 3$ complex in IGROV1 cells. IGROV1 cells were treated with $5 \mu \mathrm{M} 3$ for $6 \mathrm{~h}$, and then fixed and immunostained for ER $\alpha$ or ER $\beta$ (red) and compound 3 (green). IgG, negative control. Yellow pixels represent $E R \beta / 3$ colocalization, indicating the formation of an ER $\beta / 3$ complex. Bar $=20 \mu \mathrm{m}$.

\subsubsection{Compound 3: Nuclear Localization, ER $\beta$ on Chromatin Colocalization, and Molecular Docking}

The LC-ESI-MS was validated for the nuclear localization and quantitative determination of compound 3. The concentration-time profile of compound 3 in the IGROV1 nuclear fraction is shown in Figure 4a. Nuclear lipids from IGROV1 cells exposed for 6, 12, 24, or $48 \mathrm{~h}$ to compound 3 were extracted, and LC-MS analysis performed as described in the Supplementary Materials (Page S2). Compound 3 nuclear concentration (expressed as $\mu \mathrm{g} / \mathrm{mg}$ pellet) was found to increase from 6 to $24 \mathrm{~h}$ and decrease at a concentration under the quantitation limit after $48 \mathrm{~h}$.

Next, chromatin binding of ER $\beta$ and compound 3 was assessed. IGROV1 cells were treated with compound 3 for $6 \mathrm{~h}$ and then lysed by CSK + buffer to remove soluble proteins, leaving chromatin and chromatin-bound proteins (CBP) intact (Figure $4 b$ ). ER $\beta / \mathbf{3}$ complex colocalizes on chromatin, and both $E R \beta$ and compound 3 staining are absent in DNase treated cells, demonstrating the dependence of specific signals on intact chromatin (Figure $4 b$ ).

In an attempt to explain these data at a molecular level, the interaction of compound $\mathbf{3}$ with ER $\beta$ was investigated by a computational approach. We analyzed the location and orientation of the evaluated compound and the interactions into the binding site of the selected $\operatorname{Er} \beta$. The predicted binding free energy (BE) was used as the criterion for ranking. The conformation with the lowest ranking docked binding energy (BE) was considered to be the "best" docking result. Docking on the interaction between the indole derivative 3 and ER $\beta$ was performed; virtual constants of inhibition $(\mathrm{Ki})$ at micromolar concentration were measured. Compound 3 docks and nicely fits into the active site of the $E R \beta$, as indicated by the binding free energy $[\Delta \mathrm{G}]$ reported $(\mathrm{BE}:-7.11 \mathrm{kcal} / \mathrm{mol})$ and calculated $\mathrm{KI}$ (Constant of inhibition) equal to $6.19 \mu \mathrm{M}$. The analysis of compound 3 binding pose inside the ER $\beta$ active site shows that it can form a hydrogen bond between the $-\mathrm{OH}$ group of an indole moiety with THR299. Compound 3 is stabilized into the ER $\beta$ active site through interactions between the 5- $\AA$ surrounding polar MET295, MET296, and MET479 and the methoxy group of the indole moiety; between LYS300 and ASP303 residues and dihydro-indole-one moiety; and between aromatic LEU476, 
LEU477, and VAL487 and Cl-ethyl-benzene of compound 3 . The best binding pose of 3 into the ER $\beta$ active binding site is shown in Figure 4c.

a

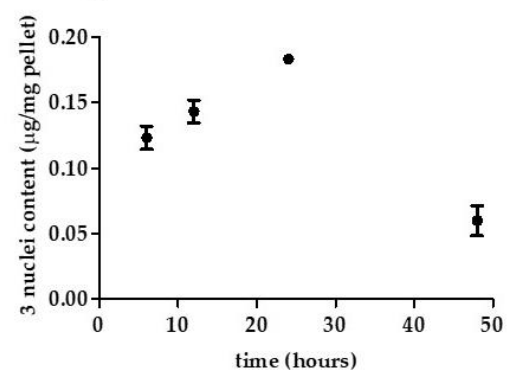

c

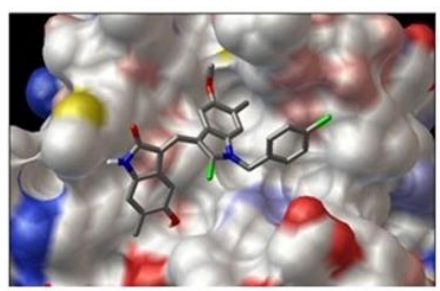

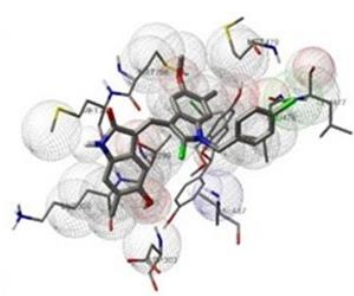

b

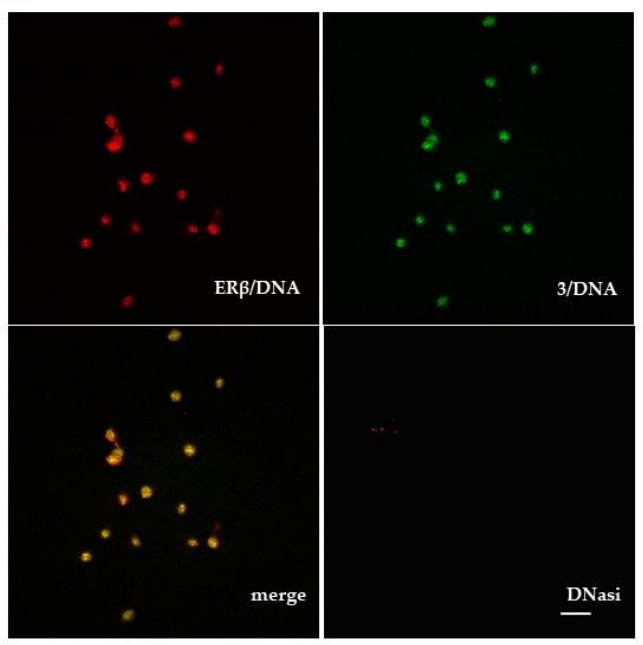

Figure 4. Nuclear localization, ER $\beta$ on chromatin colocalization, and molecular docking: (a) Nuclear content profile of compound 3 at different incubation times $(n=3)$. The results are obtained by analyzing the sample in SIM modality on the ESI generated ions at $m / z 493$ and the quantitation results from the total of cis and trans content. (b) ER $\beta / 3$ complex binds chromatin. Yellow pixels represent $\mathrm{ER} \beta / 3$ colocalization. In the negative control, lysis was followed by DNase I treatment. Bar $=20 \mu \mathrm{m}$. (c) The images show the lowest energy conformation of compound 3 into the ER $\beta$ binding site: (left) the best docking binding pose of compound 3 is shown into the pocket binding site of ER $\beta$; and (right) the amino acid residues of the ER $\beta$ binding site within $5 \AA$ from compound 3 are displayed.

\subsubsection{Mass Spectrometry-Based Assessment of Histone Acetylation}

To assess if the treatment with $\mathbf{3}$ involves changes in the histones post-translational modifications (PTMs) pattern, mass spectrometry-based analyses of histones extracted from IGROV1 were carried out on control cells and after treatment with compound 3 (see Page S3); to this purpose, both top-down and bottom-up approaches were exploited as previously described [26,27]. In particular, the liquid chromatography-mass spectrometry (LC-MS) analysis performed on isolated histones allowed the identification and quantification of the most abundant PTMs. This highly informative approach showed that treatment with compound 3 induces a significant increment in the $\mathrm{H} 4$ acetylation degree while it does not affect the PTM profile of other histone proteins (data not shown). The global increase of the $\mathrm{H} 4$ acetylation degree translates, after treatment with compound 3 , into the increment of the relative abundance of the forms carrying more than one acetylation (from 2 to 4 ) with a concomitant decrease of the monoacetylated form (Figure 5). The increment in the acetylation degree was also found to be dependent on the incubation time of compound 3 in IGROV1 cells and it is therefore sharper after $24 \mathrm{~h}$ of treatment.

MALDI-TOF analysis of the $\mathrm{H} 4$ peptides, obtained after the endoproteinase Arg-C digestion (Supplementary Materials: S4,S5, confirmed that the increment of the acetylation degree concerns the N-terminal tail of the protein (Figure S2). 
a

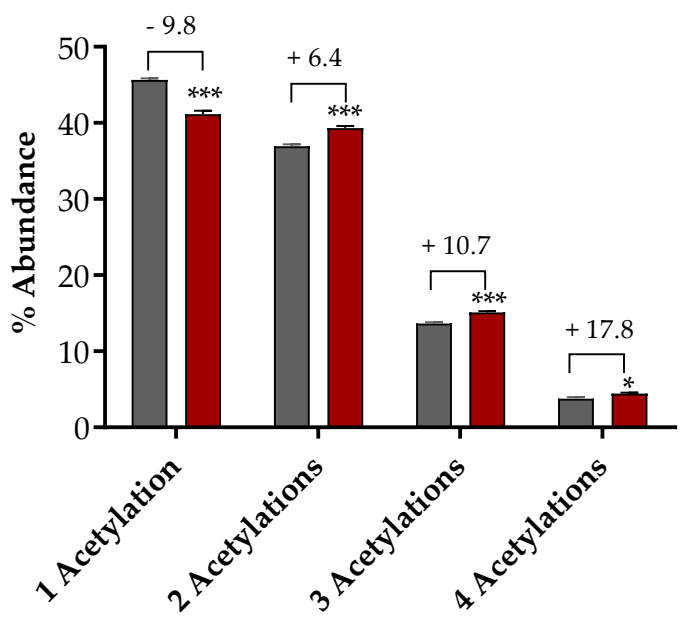

b

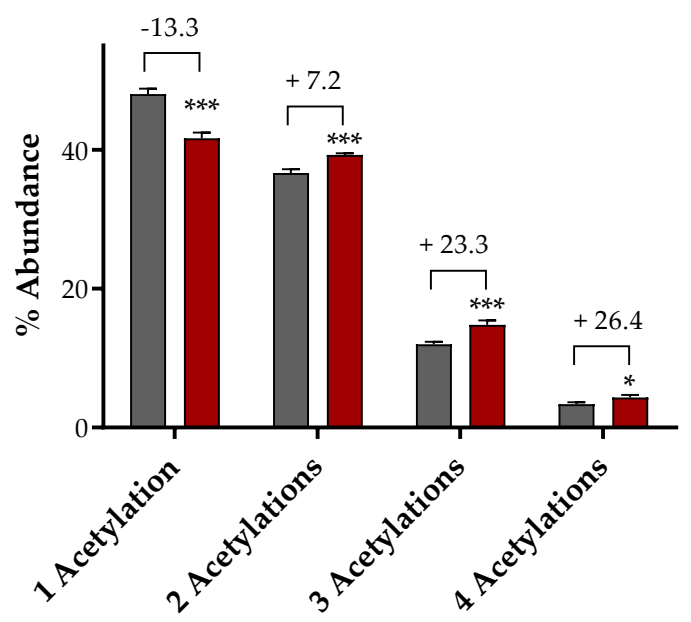

Figure 5. Compound 3 induces an increase of $\mathrm{H} 4$ acetylation degree. The histograms report the relative abundance of histone $\mathrm{H} 4$ isoforms grouped on the basis of their acetylation status obtained from the analysis of the deconvoluted ESI mass spectrum. Histones were extracted from IGROV1 cells after treatment with 3 (red) or from untreated cells (gray) for: $6 \mathrm{~h}(\mathbf{a})$; or $24 \mathrm{~h}(\mathbf{b})$. Above the bar, the percent difference between the control and compound 3 is reported. ${ }^{*} p<0.05,{ }^{* * *} p<0.001$.

\subsubsection{Compound 3 Induces Gene and Protein Expression Modulations}

To investigate the observed cytostatic effect of compound 3, transcription levels of CCND1, c-MYC (MYC), P21 (CDKN1A), P16 (CDKN2A), and ER $\beta$ (ESR2) genes, which control cell proliferation, were analyzed by Real-Time Polymerase Chain Reaction (RT-PCR). The analysis was performed on cDNA of control and compound 3-treated cells, and the $\Delta \Delta \mathrm{C}_{\mathrm{T}}$ method was used with G3PDH as the housekeeping gene (a list of primers for quantitative RT-PCR is shown in Table S1). Relative transcription levels after 6 or $24 \mathrm{~h}$ treatment, expressed as means of fold changes, are reported in Figures $6 \mathrm{a}$ and $7 \mathrm{a}$, respectively.

At $6 \mathrm{~h}$ of treatment, compound 3 administration does not affect CDKN1A and ESR2 transcription, while it significantly upregulates CDKN2A and simultaneously downregulates CCND1 and MYC. Cyclin D1, c-myc, and p16 protein expressions were analyzed by spectral confocal microscopy in control and 24-h treated cells. Compound 3 administration determines a drastic decrease in cyclin D1 (Figure 6b) and similar results were obtained for c-myc (data not shown), while it significantly increases p16 expression (Figure $6 \mathrm{~b}$ ), causing an arrest of cell proliferation.

At $24 \mathrm{~h}$ of treatment, the most significant modifications of gene expression are represented by a downregulation of CCND1 and an upregulation of ESR2, while there are no differences in the expression of MYC, CDKN1, and CDKN2. Interestingly, the increase in ESR2 is due to an overexpression of the ER $\beta 1$ isoform alone, while the $\beta 2$ and $\beta 5$ isoforms decrease significantly (Figure 7a). Figure $7 \mathrm{~b}$ shows how the levels of ER $\beta$ have increased, and Figure $7 \mathrm{c}$ shows that the increase in protein contents of this receptor is supported by the ER $\beta 1$ isoform, while those of cyclin D1 remain decreased (data not shown). 


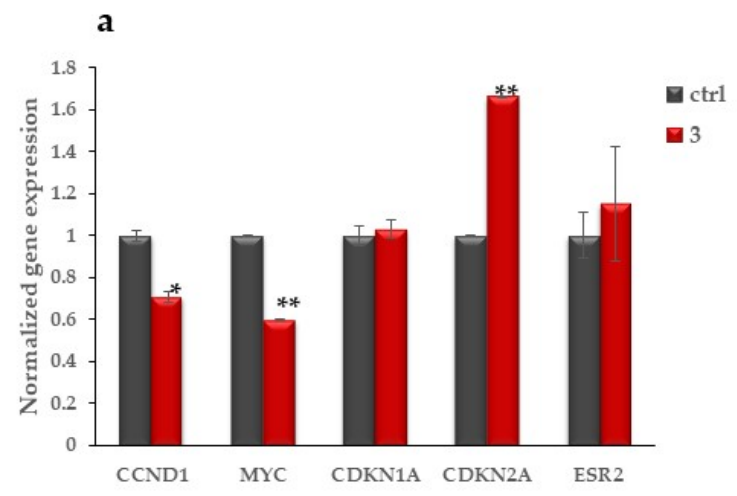

b
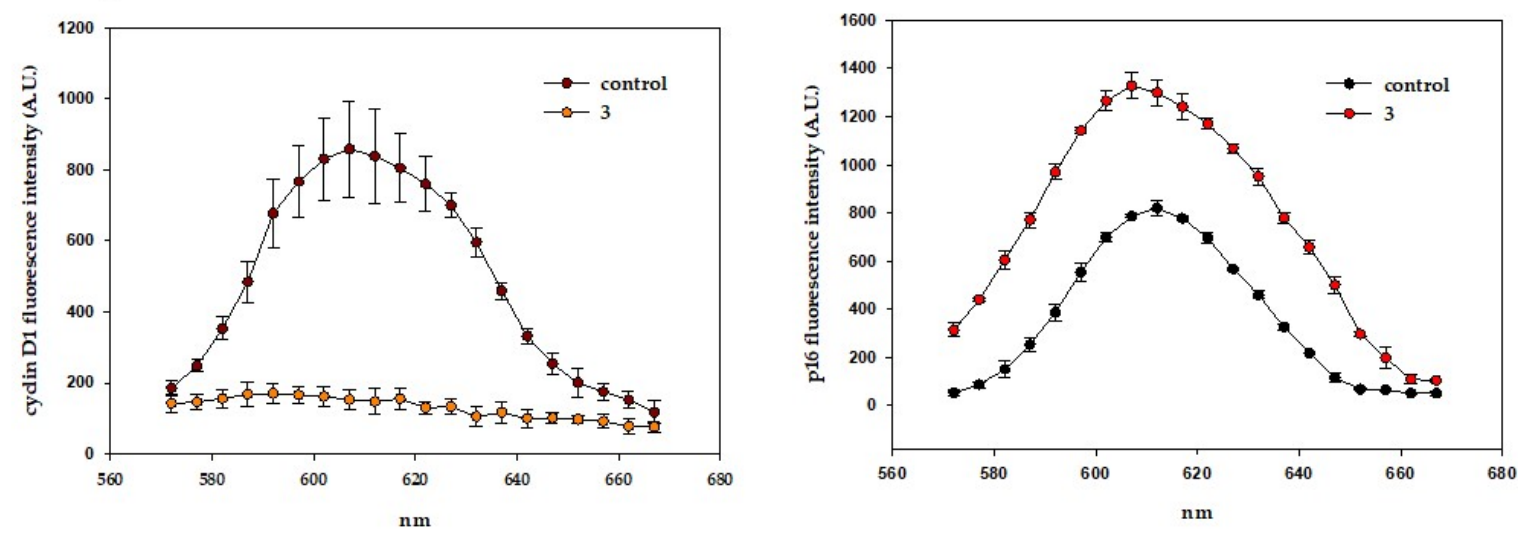

Figure 6. Compound 3 modifies gene and protein expression: (a) gene expression for CCND1, MYC, CDKN1A, CDKN2A, and ESR2 analyzed by RT-PCR after $6 \mathrm{~h}$ of treatment; and (b) fluorescence spectra of cyclin D1 (left) and p16 (right) under $568 \mathrm{~nm}$ laser excitation. Data shown are the result of five separate experiments. ${ }^{*} p<0.05,{ }^{* *} p<0.01$.
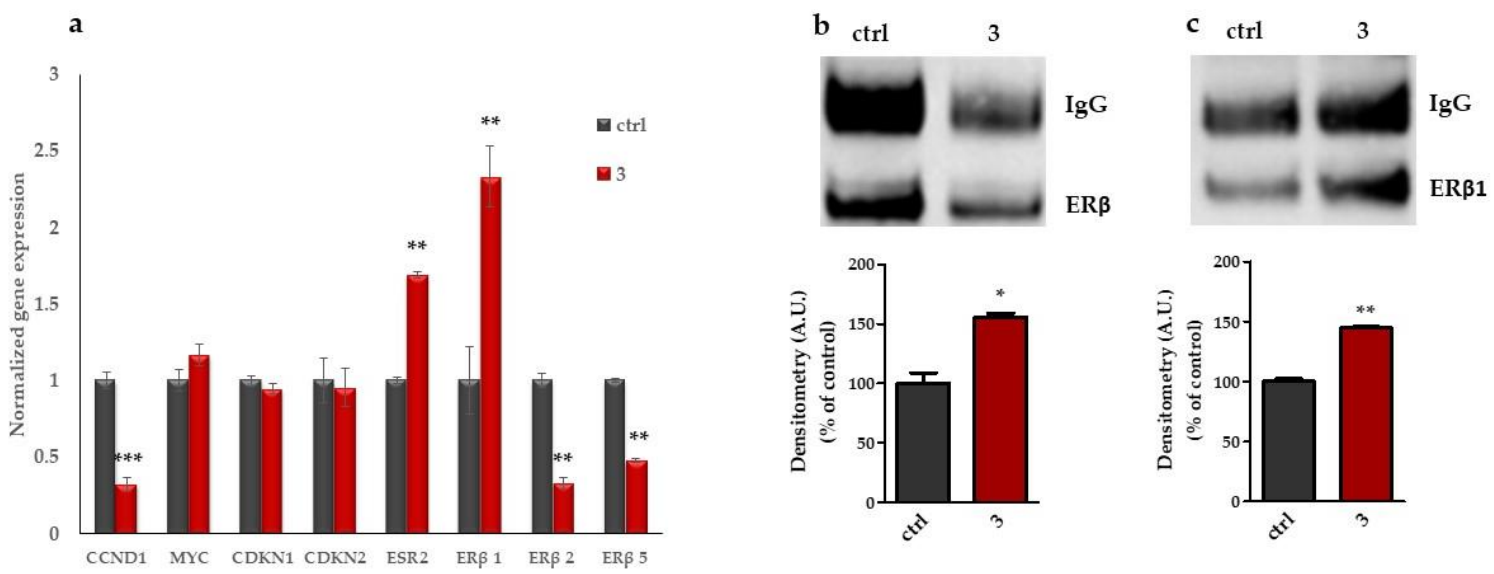

Figure 7. Compound 3 modifies ESR2 isoform expression in IGROV1: (a) gene expression for CCND1, MYC, CDKN1A, CDKN2A, ESR2, ER $\beta 1, \beta 2$, and $\beta 5$ analyzed by RT-PCR after $24 \mathrm{~h}$ of treatment; and $(\mathbf{b}, \mathbf{c})$ immunoprecipitation and Western blot analysis of ER $\beta$ and $\beta 1$ (top). Cell lysates from control and IGROV1 treated with 3 for $48 \mathrm{~h}$ were immunoprecipitated with anti ER $\beta$ or $\beta 1$ antibodies; and (bottom) relative quantification of ER $\beta$ and $\beta 1$. Densitometry arbitrary units (A.U.) were normalized by IgG. Results are given as means \pm SD of three independent experiments and are compared to controls, taken as $100 \%$. ${ }^{*} p<0.05,{ }^{* *} p<0.01$. 


\section{Discussion}

In a previous work, the antiproliferative effect induced by compound 3 in different ovarian cancer cell lines has been described [25]. Here, we continued the studies on the effects of compound 3 using, as a model, an ovarian cancer line, IGROV1, which expresses both ER $\alpha$ and ER $\beta$ receptors.

Compound 3 administered to IGROV1 decreases cell growth by $66 \%$ already $24 \mathrm{~h}$ after treatment and by $82 \%$ after $72 \mathrm{~h}$ (Figure $2 \mathrm{a}$ ). Such a decrease is due to a time-dependent arrest in the G0/G1 phase of the cell cycle, with a nearly complete synchronization (87\%) after $72 \mathrm{~h}$ of treatment (Figure 2b).

We then explored the effect on IGROV1 growth of the non-subtype-selective, natural hormone $\mathrm{E} 2$, both alone and associated to compound 3. In the presence of both ER subtypes, compound 3 has a dominant inhibitory effect on cell growth, antagonizing the growth stimulatory effect of ER $\alpha$ (Figure 2c). The colocalization analysis reveals that 3 forms a complex only with ER $\beta$ (Figure 3). Moreover, the binding of the ER $\beta / 3$ complex to DNA demonstrates that the effects on cell proliferation induced by compound 3 are due to its interaction with ER $\beta$ (Figure $4 b$ ). Its molecular interaction with ER $\beta$ was also confirmed by using a computational approach (Figure 4c).

$\mathrm{ER} \beta$ levels and/or the $\mathrm{ER} \beta / \mathrm{ER} \alpha$ ratio decrease along with ovarian carcinogenesis, indicating that the loss of ER $\beta$ expression may be involved in carcinogenesis [16,18,28,29].

We then focused on exploring the effect of compound 3 on the histone acetylation and gene expression in IGROV1. At $6 \mathrm{~h}$ of treatment, compound 3 induces an increase of acetylated $\mathrm{H} 4$ isoforms (Figure 5) and a downregulation of MYC and CCND1 genes (Figure 6a), acting as an ER $\beta$ agonist, in accordance with other findings on other agonists [30,31].

Moreover, we did not find significant changes in the expression of CDKN1A and ESR2 genes, but, interestingly, a significant upregulation of CDKN2A gene (Figure 6a) and the corresponding protein product p16 (Figure 6b) was found. CDKN2A is located on chromosome 9p21 and plays an important role in cell cycle regulation by slowing cells progression from $\mathrm{G} 1$ to $S$ phase [32,33]. It has become clear that the expression of CDKN2A is reduced by DNA methylation [18,34,35]. In addition, CDKN2A inactivation upregulates RB, stimulating the cyclin-dependent kinases (CDKs) and the RB pathway, which leads to malfunction of cell proliferation and apoptosis, thereby further facilitating carcinogenesis [36]. Indeed, several types of cancer, including ovarian cancer, exhibit a methylation phenotype of CDKN2A [37-39]. Interestingly, other authors have suggested that aberrant methylation of CDKN2A promoter may be essential to the initiation of ovarian cancer and in distinguishing malignant from healthy ovarian tissues. Besides, CDKN2A promoter methylation is a potential predictive factor for poor prognosis in ovarian cancer [40].

At $24 \mathrm{~h}$ of treatment, we repeated the analysis on gene expression and epigenetic modifications. LC-MS analysis of the purified histone H4 showed an increase of acetylation. The state of histone acetylation is closely associated with chromatin remodeling and gene regulation. Indeed, most significant modifications of gene expression are represented by a downregulation of CCND1 and an upregulation of ESR2 genes (Figure 7a). Interestingly, the increase in ESR2 is due to an overexpression of the ER $\beta 1$ isoform alone, while the $\beta 2$ and $\beta 5$ isoforms decrease significantly. This result is particularly important in ovarian tumors. In fact, it has been reported that a low level of ER $\beta 1$ may contribute to ovarian cancer metastasis, while $\beta 5$ and $\beta 2$ induce cell migration, invasion, and proliferation [14] Other authors have found that overexpression of ER $\beta 1$ represses in vitro cell migration and invasion in ovarian cancer cells [41,42], as well as reduces tumor formation in sites of metastasis in vivo [18].

\section{Materials and Methods}

\subsection{Cell Culture and Chemicals}

The human ovarian cancer cell line IGROV1 was kindly provided by Istituto Nazionale Tumori Milano, Italy. Cells were maintained in RPMI 1640 medium (Labtek Eurobio, Milan, Italy), supplemented with 10\% FBS (Euroclone, Milan, Italy) and 2 mM L-glutamine (Sigma-Aldrich, St. Louis, $\mathrm{MO}, \mathrm{USA})$ at $37^{\circ} \mathrm{C}$ and $5 \% \mathrm{CO}_{2}$. 
3-\{[2-Chloro-1-(4-chlorobenzyl)-5-methoxy-6-methyl-1H-indol-3-yl]methylene\}-5-hydroxy-6methyl-1,3-dihydro-2H-indol-2-one (3) was dissolved in dimethyl sulfoxide (DMSO) (Sigma-Aldrich, St. Louis, MO, USA) at a concentration of $20 \mathrm{mM}$. The drug was diluted in fresh medium at the final concentration of $5 \mu \mathrm{M}$, according to Andreani et al. [25]. 17-beta Estradiol (E2) (Sigma-Aldrich, S.Louis, MO, USA) was dissolved in DMSO at a concentration of $20 \mathrm{mM}$ and diluted in fresh medium at a work concentration of $1 \mathrm{nM}$.

\subsubsection{Proliferation Assays and Cell Cycle Analysis}

IGROV1 cells were plated in 6-well dishes; after $48 \mathrm{~h}$, the medium was removed and fresh medium containing the drugs added. Control cells received the corresponding volume of DMSO. The number of viable cells was determined by trypan blue exclusion.

For E2 response assay, IGROV1 cells were plated in 6-well dishes at equal density and grown in 10\% FCS for $48 \mathrm{~h}$. Cells were serum-starved for $24 \mathrm{~h}$ and then stimulated with E2 $1 \mathrm{nM}$, with or without $5 \mu \mathrm{M}$ compound 3, for an additional $24 \mathrm{~h}$. Untreated cells were used as controls. Viable cells were counted by using Trypan blue exclusion dye method.

For cell cycle assay IGROV1 cells were treated for 24,48 , and $72 \mathrm{~h}$ with compound 3 , detached with $0.11 \%$ trypsin (Sigma-Aldrich, St. Louis, MO, USA)/0.02\% ethylenediaminetetraacetic acid (EDTA) (Sigma-Aldrich, St. Louis, MO, USA), washed in PBS, and centrifuged. Flow cytometric analysis was performed as previously described. [43]

\subsubsection{Confocal Microscopy}

IGROV1 cells were grown on glass coverslips and exposed to compound $35 \mu \mathrm{M}$ for 24 or $48 \mathrm{~h}$. Cells were fixed, permeabilized, and incubated with primary antibodies against ER $\alpha, E R \beta$, (Santa Cruz Biotechnology, Dallas, TX, USA), cyclin D1 (Millipore, Billerica, MA, USA), or p16 (Santa Cruz Biotechnology, Dallas, TX, USA) overnight at $4{ }^{\circ} \mathrm{C}$, followed by appropriate Alexa 568-conjugated secondary antibody. IGROV1 cells were pre-exposed to negative control (IgG isotype) and then samples were fixed and stained with the secondary and fluorescent antibody (Alexa fluor-568). Specimens were embedded in Mowiol and analyzed in confocal microscopy by using a Nikon Plan Apo 60X oil objective.

For spectral imaging, fluorescence was detected in spectral mode in the interval 572-667 nm at 5 -nm resolution. At least 60 cells were measured and the signal corrected for background fluorescence by subtracting the fluorescence detected from the extracellular region in the same spectral image. Images were captured with a Nikon C1s confocal laser-scanning microscope (Nikon, Tokyo, Japan).

For the chromatin binding assay, IGROV1 cells were grown on glass coverslips and exposed to compound 3 for $6 \mathrm{~h}$. To visualize chromatin-bound proteins, cells were processed as described previously [44,45]. Briefly, cells were lysed in CSK + buffer for $30 \mathrm{~min}$ in ice, and then fixed and incubated with primary antibody ER $\beta$ (Santa Cruz Biotechnology, Dallas, TX) overnight at $4{ }^{\circ} \mathrm{C}$. Subsequently, samples were washed with 1\% Bovine Serum Albumin (BSA)/PBS and stained with appropriate Alexa 568-conjugated secondary antibody for $1 \mathrm{~h}$, at room temperature. To ensure that proteins remaining after in situ extraction were bound to intact chromatin, cells were treated with $200 \mathrm{U} / \mathrm{mL}$ DNase I (Promega, Madison, WI, USA) for $30 \mathrm{~min}$ at $37^{\circ} \mathrm{C}$ after being lysed in CSK + buffer. Specimens were embedded in Mowiol (Hoechst, Frankfurt, Germany) and multiple images acquired by using sequential laser excitations at 488 and $568 \mathrm{~nm}$ to reduce spectral bleed-through artifacts. The images were collected by using a Nikon C1s confocal laser-scanning microscope, equipped with a Nikon PlanApo 60X, 1.4-NA oil immersion lens.

\subsubsection{Immunoprecipitation and Western Blot Analysis}

IGROV1 cells were lysed for $1 \mathrm{~h}$ in lysis buffer according to Calonghi et al. [46]. Cell lysates were centrifuged, supernatant collected, and protein concentration determined by using the Bio-Rad protein assay method (Bio-Rad, Hercules, CA, USA). For immunoprecipitation, an aliquot of $500 \mu \mathrm{g}$ of proteins 
was incubated overnight at $4{ }^{\circ} \mathrm{C}$ with $1 \mu \mathrm{g}$ of anti-ER $\beta$ or anti-ER $\beta 1$ (Abcam, Cambridge, UK) antibody. Then, Protein A-Sepharose was added to each sample according to Parolin et al. [45]. The proteins were resolved by SDS-PAGE and immunoblotted with anti-ER $\beta$ or anti-ER $\beta 1$ antibody. Detection of immunoreactive bands was performed with a secondary antibody conjugated with horseradish peroxidase and developed with an enhanced chemiluminescence (ECL) system (GE Healthcare, Milan, Italy). Densitometry analysis was performed by Fluor-S Max MultiImager (Bio-Rad, Hercules, CA, USA), and relative quantification of both ERßs was done by using IgG signal as a control.

\subsubsection{LC-MS Based Assessment of 3 in IGROV1 Nuclei}

An LC-ESI-MS based analytical method was developed and validated for the three quantitative determinations of IGROV1 nuclei. The experimental details are reported in the Supplementary Materials (Page S2).

\subsubsection{MS-Based Determination of Histones Acetylation Degree}

The LC-MS investigation of IGROV1 histone PTMs was performed by applying the analytical method previously reported by Naldi et al. [27] and here summarized in the Supplementary Materials (Page S3). The histone H4 acetylation degree was also investigated by MALDI-TOF analysis following a previously optimized analytical method [47] as described in the Supplementary Materials (Page S4).

\subsubsection{Molecular Docking}

Molecular docking was employed to verify and understand the binding mode of 3-ESR2 interaction. The ESR2 structure was retrieved from the Protein Data Bank (PDB ID: 2QTU).

Binding modes and binding affinities of the evaluated compound within the binding site of the selected estrogen receptor ESR2 were calculated using the Autogrid 4.0 and Autodock 4.2 programs [48]

The docking calculations were then performed using the Lamarckian genetic algorithm (LGA) for ligand conformational searching to estimate the possible binding conformations of our indole derivative. During the docking process, a maximum of 150 different conformations was considered for compound 3. The conformer with the lowest binding free energy was used for further analysis.

\subsubsection{Quantitative RT-PCR}

IGROV1 cells were treated with compound 3 for 6 or $24 \mathrm{~h}$. Total RNA was isolated by RNeasy Mini kit (Qiagen, Hilden, Germany) according to the manufacturer's protocol. One microgram of RNA was reverse transcribed with RevertAid First Strand cDNA Synthesis Kit (Fermentas, Ontario, Canada) by using oligo(dT) primers. The cDNA was analyzed by RT-PCR, by employing the LightCycler FastStart DNA Master SYBR Green I Kit and the LightCycler 2.0 instrument (Roche Diagnostics, Manheim, Germany). Gene expression was quantified by the $\Delta \Delta \mathrm{C}_{\mathrm{T}}$ method using G3PDH as the housekeeping gene. The list of primers for quantitative RT-PCR are reported in Table S1. Amplicon specificity was verified by first-derivative melting curve analysis and agarose gel electrophoresis.

\subsubsection{Statistical Analysis}

All data are expressed as mean \pm SD (standard deviation). Student's test was employed for the biological experiments, statistical differences were considered significant at a value of $p<0.05$, and are reported as $p<0.05\left(^{*}\right), p<0.01\left(^{* *}\right)$, and $\left.p<0.0011^{* * *}\right)$. ESI-QTOF and MALDI-TOF experiments were repeated at least three times, on three independent samples. ANOVA test was used for repeated measurement values. A $p$ value below 0.05 was considered significant.

\section{Conclusions}

The results of this study strongly support the potential of compound 3 as an ER $\beta$ agonist for the treatment of ovarian cancer and provide evidence that it promotes tumor suppression pathways 
by modulating gene expression. The most important considerations that make this compound still interesting are as follows: (i) The effect that compound 3 has in common with other ER $\beta$ agonists is the downregulation of the CCND1 gene, while the effect that differentiates it is given by the upregulation of CDKN2A. A decrease in cyclin D1 associated with an increase in the p16 protein causes an arrest of proliferation in the G0/G1 phase of the cell cycle. As reported in the literature [49,50], cyclin D1 not only promotes the G1/S-phase transition by binding and activating Cdk4 and Cdk6, but it also plays a very important role in DNA damage repair mechanisms, especially in homologous recombination-directed repair (HDR). Cyclin D1 is recruited to damaged foci by BRCA2 and enhances RAD51 binding to BRCA2. Furthermore, cyclin D1 is essential for RAD51 gene upregulation in case of double-stranded break (DSB). Thus, the combined treatment of a drug leading to a depletion of cyclin D1 and a DNA damage inducer, such as irradiation, could be an interesting potential therapy to target cancers with a high rate of DNA repair, especially in the case of chemo- and radio-resistant tumors. (ii) Compound 3 induces a decrease in the $E R \beta 2-\beta 5$ isoforms' gene expression. Unfortunately, studies on the functional roles of ER $\beta 2$ and $\beta 5$ in cancers are limited, as are studies on their molecular mechanisms of action. However, recent papers show that ER $\beta 5$ and $\beta 2$ play an important role in ovarian tumorigenesis by regulating cell migration, invasion, and proliferation, suggesting for them a role as potential prognostic markers and therapeutic targets $[13,14]$.

Supplementary Materials: Supplementary LC-ESI-MS and MALDI TOF material, list of primers for quantitative RT-PCR.

Author Contributions: Conceptualization, N.C. and L.V.; methodology, C.B. (Carla Boga), J.F., M.N., E.S., R.M. and G.M.; investigation, J.F., M.N. and E.S.; data curation, C.B. (Carla Boga), J.F., M.N., E.S., R.M. and G.M.; writing - original draft preparation, N.C, L.V., J.F., M.N. and E.S.; writing-review and editing, V.A. and A.L.; and supervision, C.B. (Carlo Bertucci). All authors have read and agreed to the published version of the manuscript.

Funding: This research received no external funding.

Acknowledgments: We are grateful to Professor Lanfranco Masotti for the helpful discussion. This work was supported by grants from RFO ex $60 \%$ (N.C.). The authors are grateful for the possibility to use the mass spectrometric instrumentation at the Center for Applied Biomedical Research (C.R.B.A.), University of Bologna, Italy.

Conflicts of Interest: The authors declare no conflict of interest.

\section{References}

1. Vargas, A.N. Natural history of ovarian cancer. Ecancermedicalscience 2014, 8, 465. [PubMed]

2. National Cancer Institute. Surveillance, Epidemiology, and End Results Program. Cancer stat facts: Ovarian cancer. Available online: https://seer.cancer.gov/statfacts/html/ovary.html (accessed on 30 December 2018).

3. Chen, G.G.; Zeng, Q.; Tze, G.M. Estrogen and its receptors in cancer. Med. Res. Rev. 2008, 28, 954-974. [CrossRef] [PubMed]

4. Li, A.J.; Baldwin, R.L.; Karlan, B.Y. Estrogen and progesterone receptor subtype expression in normal and malignant ovarian epithelial cell cultures. Am. J. Obstet. Gynecol. 2003, 189, 22-27. [CrossRef] [PubMed]

5. Matthews, J.; Gustafsson, J.A. Estrogen signaling: a subtle balance between ER alpha and ER beta. Mol. Interv. 2003, 3, 281-292. [CrossRef] [PubMed]

6. Pujol, P.; Rey, J.-M.; Nirde, P.; Roger, P.; Gastaldi, M.; Laffargue, F.; Rochefort, H.; Maudelonde, T. Differential expression of estrogen receptor-alpha and -beta messenger RNAs as a potential marker of ovarian carcinogenesis. Cancer Res. 1998, 58, 5367-5373. [PubMed]

7. Jia, M.; Dahlman, K.; Gustafsson, J.Å. Estrogen receptor alpha and beta in health and disease. Best Pract. Res. Clin. Endocrinol. Metab. 2015, 29, 557-568. [CrossRef]

8. Liu, M.M.; Albanese, C.; Anderson, C.M.; Hilty, K.; Webb, P.; Uht, R.M.; Price, R.H., Jr.; Pestell, R.G.; Kushner, P.J. Opposing action of estrogen receptors alpha and beta on cyclin D1 gene expression. J. Biol. Chem. 2002, 277, 24353-24360. [CrossRef]

9. Planas-Silva, M.D.; Weinberg, R.A. Estrogen-dependent cyclin E-cdk2 activation through p21 redistribution. Mol. Cell Biol. 1997, 17, 4059-4069. [CrossRef]

10. Worsley, S.D.; Ponder, B.A.; Davies, B.R. Overexpression of cyclin D1 in epithelial ovarian cancers. Gynecol. Oncol. 1997, 64, 189-195. [CrossRef] 
11. Moore, J.T.; McKee, D.D.; Slentz-Kesler, K.; Moore, L.B.; Jones, S.A.; Horne, E.L.; Su, J.L.; Kliewer, S.A.; Lehmann, J.M.; Willson, T.M. Cloning and characterization of human estrogen receptor beta isoforms. Biochem. Biophys. Res. Commun. 1998, 247, 75-78. [CrossRef]

12. Suzuki, F.; Akahira, J.; Miura, I.; Suzuki, T.; Ito, K.; Hayashi, S.; Sasano, H.; Yaegashi, N. Loss of estrogen receptor beta isoform expression and its correlation with aberrant DNA methylation of the $5^{\prime}$-untranslated region in human epithelial ovarian carcinoma. Cancer Sci. 2008, 99, 2365-2372. [CrossRef] [PubMed]

13. Ciucci, A.; Zannoni, G.F.; Travaglia, D.; Petrillo, M.; Scambia, G.; Gallo, D. Prognostic significance of the estrogen receptor beta (ERbeta) isoforms ERbeta1, ERbeta2, and ERbeta5 in advanced serous ovarian cancer. Gynecol. Oncol. 2014, 132, 351-359. [CrossRef] [PubMed]

14. Chan, K.K.L.; Siu, M.K.Y.; Jiang, Y.; Wang, J.; Wang, Y.; Leung, T.H.Y.; Liu, S.S.; Cheung, A.N.Y.; Ngan, H.Y.S. Differential expression of estrogen receptor subtypes and variants in ovarian cancer: Effects on cell invasion, proliferation and prognosis. BMC Cancer 2017, 17, 606. [CrossRef] [PubMed]

15. De Stefano, I.; Zannoni, G.F.; Prisco, M.G.; Fagotti, A.; Tortorella, L.; Vizzielli, G.; Mencaglia, L.; Scambia, G.; Gallo, D. Cytoplasmic expression of estrogen receptor beta $(\mathrm{ERb})$ predicts poor clinical outcome in advanced serous ovarian cancer. Gynecol. Oncol. 2011, 122, 573-579. [CrossRef]

16. Bardin, A.; Boulle, N.; Lazennec, G.; Vignon, F.; Pujol, P. Loss of ERbeta expression as a common step in estrogen-dependent tumor progression. Endocr. Relat. Cancer 2004, 11, 537-551. [CrossRef]

17. Rutherford, T.; Brown, W.D.; Sapi, E.; Aschkenazi, S.; Munoz, A.; Mor, G. Absence of estrogen receptor-beta expression in metastatic ovarian cancer. Obstet. Gynecol. 2000, 96, 417-421.

18. Bossard, C.; Busson, M.; Vindrieux, D.; Gaudin, F.; Machelon, V.; Brigitte, M.; Jacquard, C.; Pillon, A.; Balaguer, P.; Balabanian, K.; et al. Potential role of estrogen receptor beta as a tumor suppressor of epithelial ovarian cancer. PLoS ONE 2012, 7, e44787. [CrossRef]

19. Fekete, T.; Raso, E.; Pete, I.; Tegze, B.; Liko, I.; Munkacsy, G.; Sipos, N.; Rigo, J., Jr.; Gyorffy, B. Meta-analysis of gene expression profiles associated with histological classification and survival in 829 ovarian cancer samples. Int. J. Cancer 2012, 131, 95-105. [CrossRef]

20. Veenema, G.H.; Ottow, E.; Weinmann, H. Subtype-Selective estrogens in Nuclear Receptors as Drug Targets. In Methods and Principles in Medicinal Chemistry Series; Mannhold, R., Kubinyi, H., Folkers, G., Eds.; WILEY-VCH Verlag GmbH \& Co. KGaA: Weinheim, Germany, 2008; Chapter 4; Volume 39.

21. Mersereau, J.E.; Levy, N.; Staub, R.E.; Baggett, S.; Zogric, T.; Chow, S.; Ricke, W.A.; Tagliaferri, M.; Cohen, I.; Bjeldanes, L.F.; et al. Liquiritigenin is a plant-derived highly selective estrogen receptor $\beta$ agonist. Mol. Cell. Endocrin. 2008, 283, 49-57. [CrossRef]

22. Lattrich, C.; Schüler, S.; Häring, J.; Skrzypczak, M.; Ortmann, O.; Treeck, O. Effects of a combined treatment with tamoxifen and estrogen receptor $\beta$ agonists on human breast cancer cell lines. Arch. Gynecol. Obstet. 2014, 289, 163-171. [CrossRef]

23. Manas, E.S.; Unwalla, R.-J.; Xu, Z.B.; Malamas, M.S.; Miller, C.P.; Harris, H.A.; Hsiao, C.; Akopian, T.; Hum, W.-T.; Malakian, K.; et al. Structure-Based Design of Estrogen Receptor- $\beta$ Selective Ligands. J. Am. Chem. Soc. 2004, 126, 15106-15119. [CrossRef] [PubMed]

24. Gribble, G.W. Indole Ring Synthesis: From Natural Products to Drug Discovery; John Wiley \& Sons: Chichester, UK, 2016.

25. Andreani, A.; Burnelli, S.; Granaiola, M.; Leoni, A.; Locatelli, A.; Morigi, R.; Rambaldi, M.; Varoli, L.; Calonghi, N.; Cappadone, C.; et al. Substituted E-3-(2-chloro-3-indolylmethylene)1,3-dihydroindol-2-ones with antitumor activity. Effect on the cell cycle and apoptosis. J. Med. Chem. 2007, 50, 3167-3172. [CrossRef]

26. Naldi, M.; Andrisano, V.; Fiori, J.; Calonghi, N.; Pagnotta, E.; Parolin, C.; Pieraccini, G.; Masotti, L. Histone proteins determined in a human colon cancer by high-performance liquid chromatography and mass spectrometry. J. Chromatogr. A 2006, 1129, 73-81. [CrossRef]

27. Naldi, M.; Calonghi, N.; Masotti, L.; Parolin, C.; Valente, S.; Mai, A.; Andrisano, V. Histone post-translational modifications by HPLC-ESI-MS after HT29 cell treatment with histone deacetylase inhibitors. Proteomics 2009, 9, 5437-5445. [CrossRef] [PubMed]

28. Chan, K.K.; Leung, T.H.; Chan, D.W.; Wei, N.; Lau, G.T.; Liu, S.S.; Siu, M.K.; Ngan, H.Y. Targeting estrogen receptor subtypes (ER $\alpha$ and $E R \beta)$ with selective ERmodulators in ovarian cancer. J. Endocrinol. 2014, 221, 325-336. [CrossRef] [PubMed] 
29. Lazennec, G. Estrogen receptor beta, a possible tumor suppressor involved in ovarian carcinogenesis. Cancer Lett. 2006, 231, 151-157. [CrossRef] [PubMed]

30. Paruthiyil, S.; Parmar, H.; Kerekatte, V.; Cunha, G.R.; Firestone, G.L.; Leitman, D.C. Estrogen receptor $\beta$ inhibits human breast cancer cell proliferation and tumor formation by causing a G2 cell cycle arrest. Cancer Res. 2004, 64, 423-428. [CrossRef]

31. Schüler-Toprak, S.; Moehle, C.; Skrzypczak, M.; Ortmann, O.; Treeck, O. Effect of estrogen receptor $\beta$ agonists on proliferation and gene expression of ovarian cancer cells. BMC Cancer 2017, 17, 319. [CrossRef]

32. Serrano, M.; Hannon, G.J.; Beach, D. A new regulatory motif in cell-cycle control causing specific inhibition of cyclin D/CDK4. Nature 1993, 366, 704-707. [CrossRef]

33. Qin, Y.; Liu, J.Y.; Li, B.; Sun, Z.L.; Sun, Z.F. Association of low p16INK4a and p15INK4b mRNAs expression with their $\mathrm{CpG}$ islands methylation with human hepatocellular carcinogenesis. World J. Gastroenterol. 2004, 10, 1276-1280. [CrossRef]

34. Kim, B.N.; Yamamoto, H.; Ikeda, K.; Damdinsuren, B.; Sugita, Y.; Ngan, C.Y.; Fujie, Y.; Ogawa, M.; Hata, T.; Ikeda, M.; et al. Methylation and expression of p16INK4 tumor suppressor gene in primary colorectal cancer tissues. Int. J. Oncol. 2005, 26, 1217-1226. [CrossRef] [PubMed]

35. Gao, S.J.; Zhang, G.F.; Zhang, R.P. High CpG island methylation of p16 gene and loss of p16 protein expression associate with the development and progression of tetralogy of Fallot. J. Genet. 2016, 95, 831-837. [CrossRef] [PubMed]

36. Sharpless, N.E. INK4a/ARF: A multifunctional tumor suppressor locus. Mutat. Res. 2005, 576, $22-38$. [CrossRef] [PubMed]

37. Moselhy, S.S.; Kumosani, T.A.; Kamal, I.H.; Jalal, J.A.; Jabaar, H.S.; Dalol, A. Hypermethylation of P15, P16, and E-cadherin genes in ovarian cancer. Toxicol. Ind. Health. 2015, 31, 924-930. [CrossRef] [PubMed]

38. Di Vinci, A.; Perdelli, L.; Banelli, B.; Salvi, S.; Casciano, I.; Gelvi, I.; Allemanni, G.; Margallo, E.; Gatteschi, B.; Romani, M. p16(INK4a) promoter methylation and protein expression in breast fibroadenoma and carcinoma. Int. J. Cancer 2005, 114, 414-421. [CrossRef] [PubMed]

39. Shima, K.; Nosho, K.; Baba, Y.; Cantor, M.; Meyerhardt, J.A.; Giovannucci, E.L.; Fuchs, C.S.; Ogino, S. Prognostic significance of CDKN2A (p16) promoter methylation and loss of expression in 902 colorectal cancers: Cohort study and literature review. Int. J. Cancer 2011, 128, 1080-1094. [CrossRef] [PubMed]

40. Ruan, J.; Xu, P.; Fan, W.; Deng, Q.; Yu, M. Quantitative assessment of aberrant P16INK4a methylation in ovarian cancer: a meta-analysis based on literature and TCGA datasets. Cancer Manag. Res. 2018, 10, 3033-3046. [CrossRef]

41. Treeck, O.; Pfeiler, G.; Mitter, D.; Lattrich, C.; Piendl, G.; Ortmann, O. Estrogen receptor \{beta\}1 exerts antitumoral effects on SK-OV-3 ovarian cancer cells. J. Endocrinol. 2007, 193, 421-433. [CrossRef]

42. Zhu, J.; Hua, K.; Sun, H.; Yu, Y.; Jin, H.; Feng, Y. Re-expression of estrogen receptor beta inhibits the proliferation and migration of ovarian clear cell adenocarcinoma cells. Oncol. Rep. 2011, 26, 1497-1503.

43. Micheletti, G.; Calonghi, N.; Farruggia, G.; Strocchi, E.; Palmacci, V.; Telese, D.; Bordoni, S.; Frisco, G.; Boga, C. Synthesis of Novel Structural Hybrids between Aza-Heterocycles and Azelaic Acid Moiety with a Specific Activity on Osteosarcoma Cells. Molecules 2020, 25, 404. [CrossRef]

44. Gladden, A.B.; Diehl, J.A. The cyclin D1-dependent kinase associates with the pre- replication complex and modulates RB-MCM7 binding. J. Biol. Chem. 2003, 278, 9754-9760. [CrossRef] [PubMed]

45. Parolin, C.; Calonghi, N.; Presta, E.; Boga, C.; Caruana, P.; Naldi, M.; Andrisano, V.; Masotti, L.; Sartor, G. Mechanism and stereoselectivity of HDAC I inhibition by (R)-9-hydroxystearic acid in colon cancer. Biochim. Biophys. Acta 2012, 1821, 1334-1340. [CrossRef] [PubMed]

46. Calonghi, N.; Pagnotta, E.; Parolin, C.; Molinari, C.; Boga, C.; Dal Piaz, F.; Brusa, G.L.; Santucci, M.A.; Masotti, L. Modulation of apoptotic signalling by 9-hydroxystearic acid in osteosarcoma cells. Biochim. Biophys. Acta 2007, 1771, 139-146. [CrossRef] [PubMed]

47. Olmo, S.; Gotti, R.; Naldi, M.; Andrisano, V.; Calonghi, N.; Parolin, C.; Masotti, L.; Cavrini, V. Analysis of human histone $\mathrm{H} 4$ by capillary electrophoresis in a pullulan-coated capillary, LC-ESI-MS and MALDI-TOF-MS. Anal. Bioanal. Chem. 2008, 390, 1881-1888. [CrossRef]

48. Morris, G.M.; Huey, R.; Lindstrom, W.; Sanner, M.F.; Belew, R.K.; Goodsell, D.S.; Olson, A.J. AutoDock4 and AutoDockTools4: Automated docking with selective receptor flexibility. J. Comput. Chem. 2009, 30, 2785-2791. [CrossRef] 
49. Jirawatnotai, S.; Hu, Y.; Michowski, W.; Elias, J.E.; Becks, L.; Bienvenu, F.; Zagozdzon, A.; Goswami, T.; Wang, Y.E.; Clark, A.B.; et al. A function for cyclin D1 in DNA repair uncovered by interactome analyses in human cancers. Nature 2011, 474, 230-234. [CrossRef]

50. Di Sante, G.; Di Rocco, A.; Pupo, C.; Casimiro, M.C.; Pestell, R.G. Hormone-induced DNA damage response and repair mediated by cyclin D1 in breast and prostate cancer. Oncotarget 2017, 8, 81803-81812. [CrossRef]

Sample Availability: Samples of the compounds are not available from the authors.

(C) 2020 by the authors. Licensee MDPI, Basel, Switzerland. This article is an open access article distributed under the terms and conditions of the Creative Commons Attribution (CC BY) license (http://creativecommons.org/licenses/by/4.0/). 